\title{
A SWEAT GLAND TUMOUR OF THE HAND
}

\author{
C. M. C. Potter, Wolverhampton, England
}

It is now recognised that the commonly occurring tumours of the salivary glands, which used to be designated mixed tumours because they appeared to consist of elements derived from both ectoderm and mesoderm, are entirely of epithelial origin, and the difficulty of explaining the presence of cartilage has disappeared with the realisation that this tissue is not cartilage but epithelial cells in a lake of epithelial secretion. From time to time tumours of " mixed salivary gland type" were described, arising in sites remote from the salivary gland area, and these were considered to have arisen in heterotopic salivary gland tissue. Their histological structure closely resembled that of the salivary glands, including the

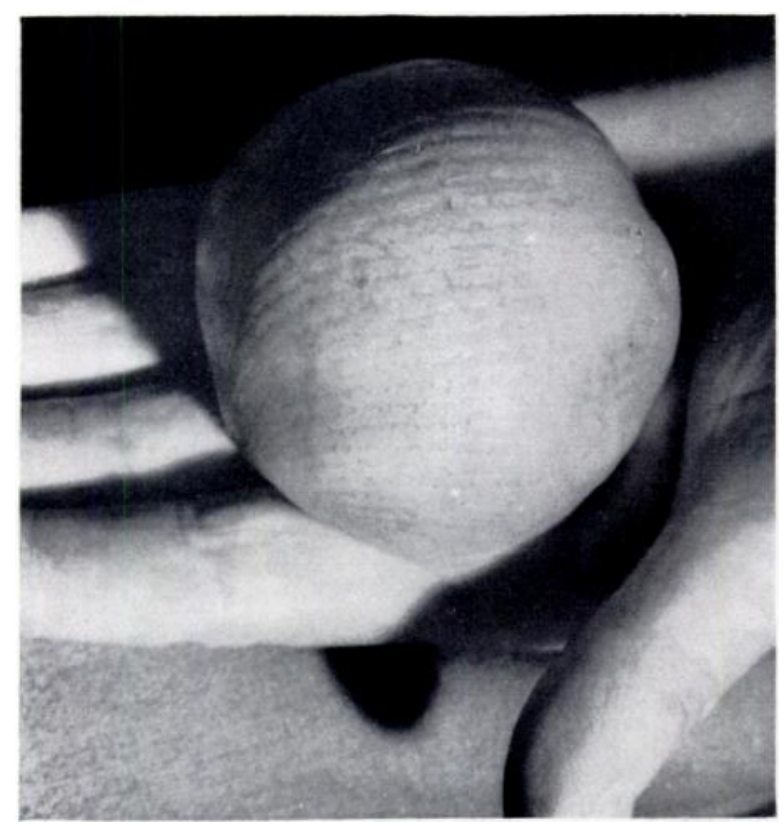

Fig. 1

The tumour before operation.

presence of the "cartilage-like" masses. This second puzzle has also been resolved, and the necessity to postulate cell rests removed, by the demonstration that these tumours have arisen in the sweat glands. Developmentally, the salivary, sweat and mammary glands have the same origin; and, in tumours arising from these various organs, striking similarities in the histology are seen. They all exhibit marked pleomorphism, and in all of them the myo-epithelial cell plays a significant part. In some of these tumours this type of cell may predominate.

The myo-epithelial cell is contractile, and numbers of them form the outer of two layers of cells forming the sweat gland. The other layer is composed of secretory cells. They have been identified in the breast as well as in the salivary and sweat glands.

Sheldon (1941) reviewed ten cases of sweat gland tumour, in three of which the myoepithelial element was predominant, and two of these three showed some malignant change. 
Simard (1938) described a tumour, the size of a pigeon's egg, removed from the hypothenar eminence. This case was included in a review of ten cases published by Highman (1944). who added a case of his own in which the tumour had grown on the hand, and in which the myo-epithelial cells were prominent. Hartz (1946) described a tumour removed from the back, and this tumour too contained a large proportion of myo-epithelial cells.

Nangle and Symmers (1950) reported a tumour which grew on the lateral side of the foot of an eighty-year-old woman. It had a slim pedicle, and by means of this it was swung out of the way in order to put on the shoe. This amicable arrangement had existed for forty years. The chief cell element present in the sections was the myo-epithelial cell. The authors of this article stated that the condition was more common than the published cases would suggest, and I therefore think it worth while to publish the following case.

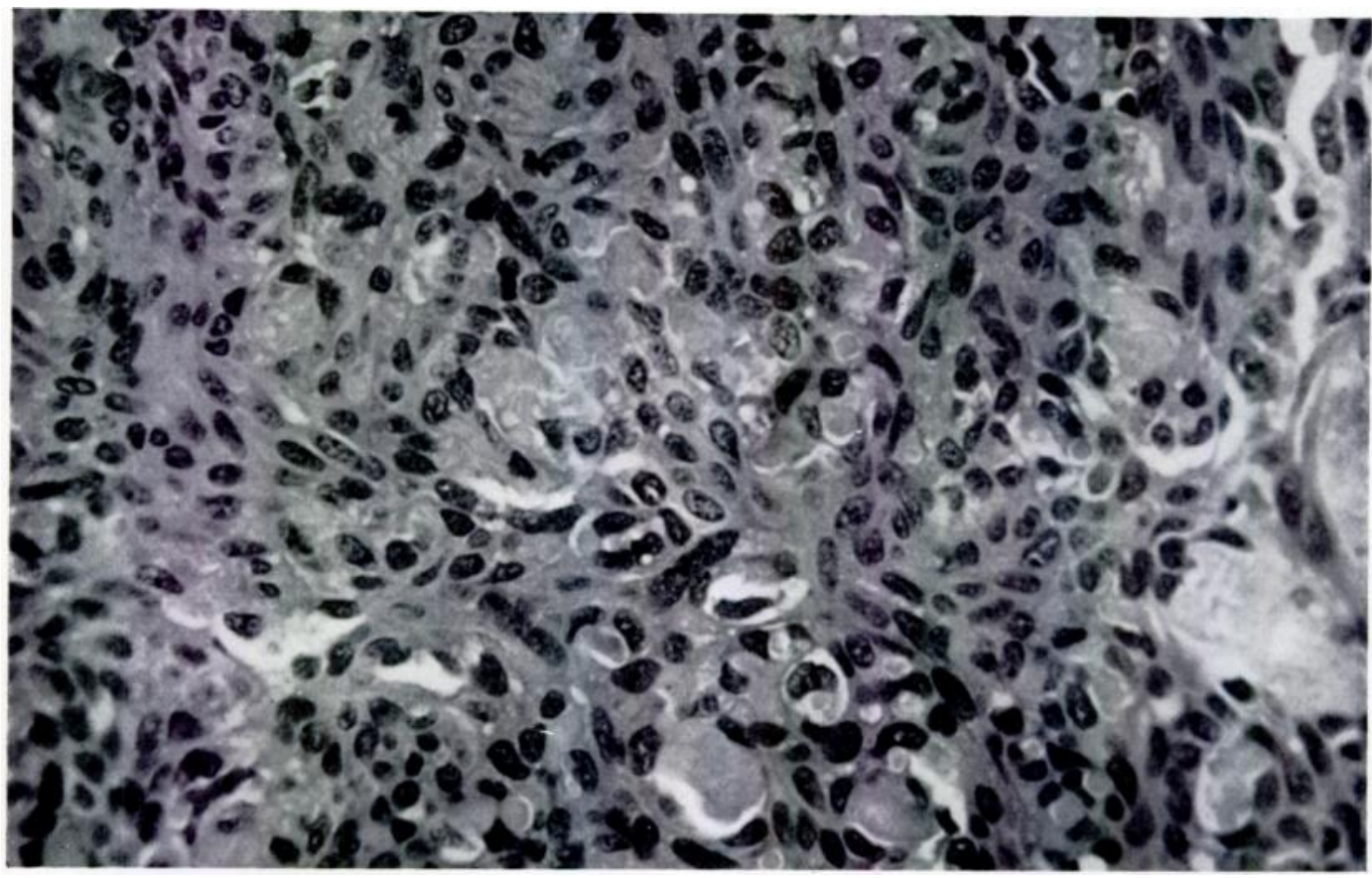

Fig. 2

Photomicrograph showing the pleomorphic structure of the tumour with the myo-epithelial cells clearly seen.

\section{CASE REPORT}

The patient was a man aged fifty-eight years. He worked at a steel works handling billets of steel with tongs, and said he had no difficulty in doing this work. He had a large tumour in the palm of his left hand which had been present for fifteen years, but which had not changed in size for many years. He thought it might have been caused by the constant trauma of the tongs he used for his work, but could not recall any actual injury.

On examination, there was seen a tumour arising from the palm and comfortably occupying the grip. The skin was stretched tightly over it, and the rugae were much enlarged. It could be seen and felt to be faintly lobulated, and was firm (Fig. 1). There was no tenderness and it never gave any pain. The tumour had no pedicle and arose from a fairly broad base, just proximal to the web between index and middle fingers. It was firmly attached and immobile.

The tumour was easily removed at operation and was completely encapsulated, with large veins running in the capsule. The wound healed primarily. 


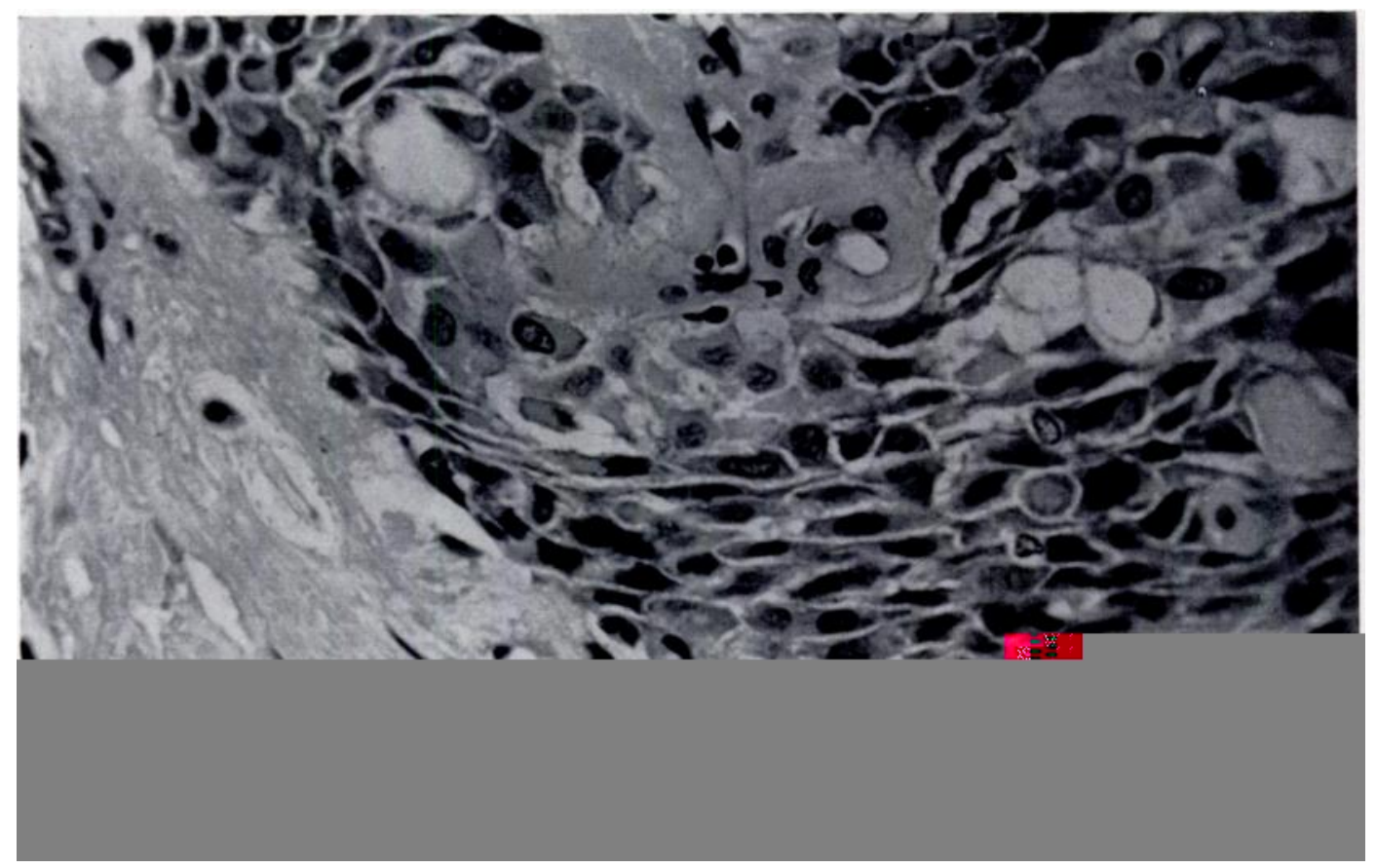

Fig. 3

A preponderance of myo-epithelial cells at the edge of one of the cell masses.

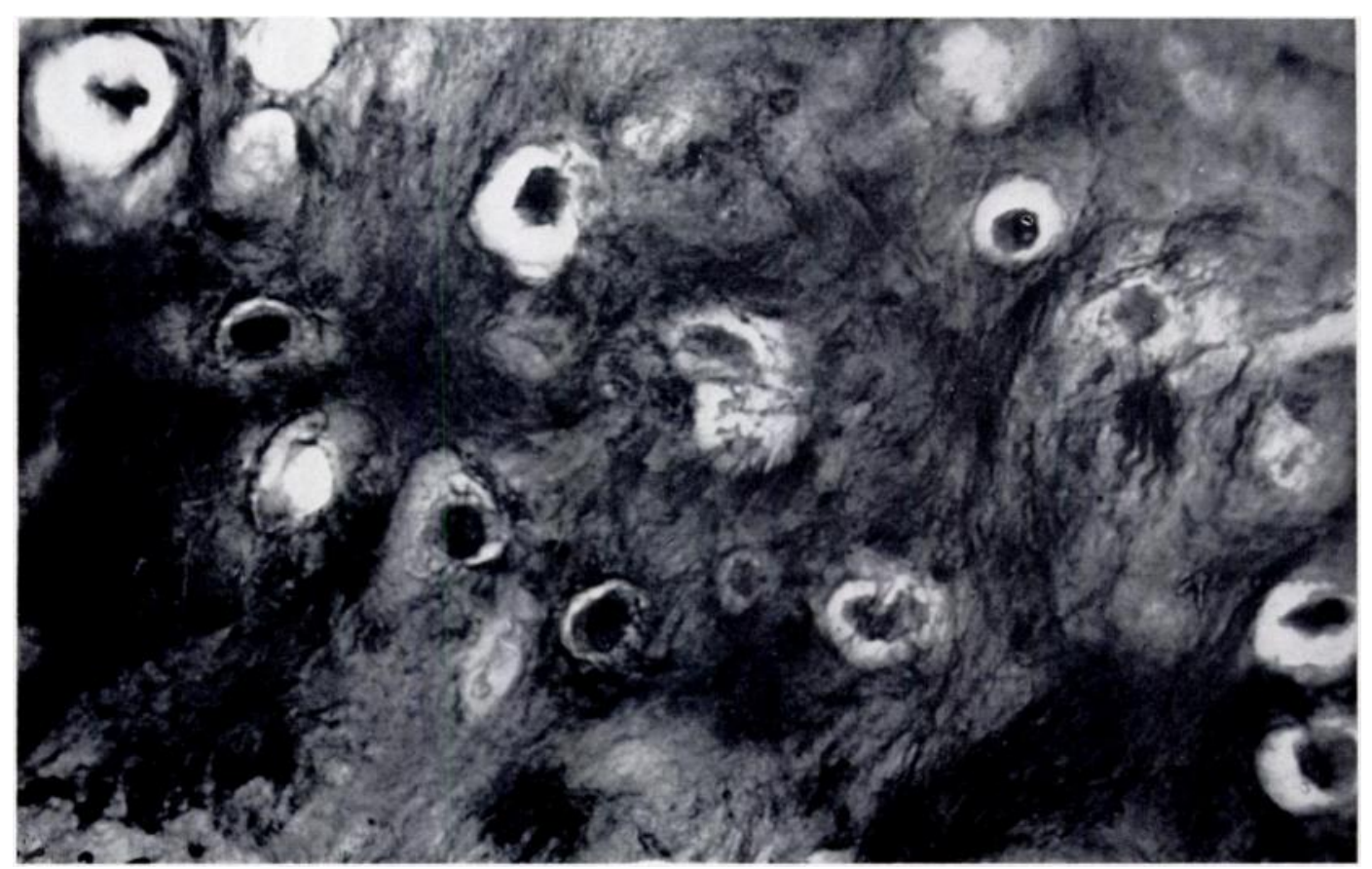

FIG. 4

A " cartilage-like" area.

THE JOURNAL OF BONE AND JOINT SURGERY 
Pathology-The specimen measured $6.5 \times 6 \times 5$ centimetres and was partly covered by a cap of skin stretched over the swelling. The under-surface of the swelling was coarsely nodular, but it appeared to be contained within a capsule. The surface showed a yellow-white, mottled, slightly shiny tissue.

Histological examination (Professor R. A. Willis) showed that the mass was undoubtedly a sweat gland tumour of pleomorphic type which has often been likened to the so-called "mixed" tumours of the salivary glands (Figs. 2 to 4). The peculiar appearance of some of the larger clumps was ascribed to predominant myo-epithelial proliferation. The "cartilage-like" areas were, like those of the salivary tumours, due to detachment of epithelial cells embedded in a lake of secretion. Judging from the long history, as well as from the uniform appearance of the tumour in most areas, it seemed certain that it was benign.

Comment-The situation of the tumour and the work done by the patient suggests the possibility that the constant slight trauma might have had some relation to the origin of the growth. In this connection it is of interest to note that Highman (1944) quoted a case reported by Kreibig (1931) in which a tumour the size of an egg had arisen at the site of a severe stone bruise on the tibia, and another case of Hirsch (1933) in which a tumour arose on the thigh at the site of repeated trauma. In his own case there was microscopic evidence of old haemorrhage. The tumour described here is unusual in its very large size and in its situation, and it is astonishing that a man could handle large steel billets with one hand full of a swelling the size of an orange.

The structure of the growth was that of the group of so-called mixed salivary gland tumours with a preponderance of the myo-epithelial element, and can therefore be regarded as a myo-epithelioma.

\section{SUMMARY}

1. The clinical appearance and histological structure of a myo-epithelial tumour of a sweat gland of the hand is described.

2. A review of previously published papers is given.

3. It is suggested that trauma may play a part in the causation of these tumours.

I am indebted to Profess or R. A. Willis and Dr A. G. Marshall for the histological report, and to Mr W. Paton for the photograph and microphotograph.

\section{REFERENCES}

Hartz, P. H. (1946): Adenomyoepithelioma of Sweat Gland. American Journal of Clinical Pathology, 16, 385. Highman, B. (1944): A Mixed Tumor of the Salivary Gland Type on the Left Hand. Archives of Pathology, 37, 387.

Hirsch, E. F. (1933): A Subcutaneous “ Mixed” Tumor (Salivary Gland Type) of the Left Thigh. Archives of Pathology, 16, 494.

KreIBIG, W. (1931): Úber ungewöhnlich gelegene Geschwülste vom Bau der Speicheldrüsenmischtumoren. Frankfurter Zeitschrift für Pathologie, 42, 281.

Nangle, E. J., and Symmers, W. St C. (1950): Pleomorphic Sweat-Gland Adenoma of the Foot. Journal of Bone and Joint Surgery, 32-B, 70.

Sheldon, W. H. (1941): The Myoepithelium in Sweat Gland Tumors. Archives of Pathology, 31, 326.

Simard, L. C. (1938): Tumour of the Palm having the Structure of a Mixed Tumour of the Salivary Glands. American Journal of Cancer, 33, 182. 